\title{
Milk yield genetic parameters estimated using random regression model in Teleorman Black Head Sheep
}

\author{
Florin Popa, Horia Grosu, Mircea-Cătălin Rotar, Rodica Ștefania \\ Pelmus, Cristina Lazăr, Mihail Alexandru Gras \\ *Corresponding author: popa1993florin@gmail.com
}

${ }^{1}$ National Research Development Institute for Animal Biology and Nutrition, IBNA Balotesti, 077015, Ilfov, Romania.

\section{ABSTRACT}

Genetic parameters are important in breeding program of sheep. For the genetic evaluation of sheep was used the random regression test-day animal model. This model was better economic that another models because reduces generation interval and reduces the costs with test-days records. Data consisted of 1050 test-day of 403 ewes in first year (2017), 752 test-day of 374 ewes in second year (2018) and 1164 test-day of 319 ewes in third year (2019). The main goal to achieve the objectives of this research were the estimation of the genetic parameters important in obtaining the breeding value by calculation heritability for test-day milk yields and the correlations between test-days milk yields, for Teleorman Black Head Sheep population from Teleorman county in three different years. The heritability for test-day milk yield ranged from 0.150 to 0.237 in 2017, from 0.212 to 0.600 in 2018 and in 2019 from 0.186 to 0.403 . Genetic correlations between sheep testdays milk yield in 2017 were positive and high.

Keywords: ewes, breeding value, genetic parameters, random regression model, test day milk yield

\section{INTRODUCTION}

Teleorman Black Head Sheep breed is a local sheep with high milk yield. Teleorman Black Head Sheep breed is rearing in Teleorman county, in Dobrotești, Mavrodin, Călinesti and Măldăeni. Ewes are lambing in spring from February to April. The lambs are weaning at 60 days and after the suckling begin the milk production of the ewes which lasts until September.

The milk production is affected by genetic and environmental factors. A multitude of factors influence sheep milk production and these are referring 
to the sheep breed, environmental conditions which involves lactation ranking of the ewe, lactation phase, litter size and also the feeding and animal health (Komprej et al., 2012). Macciotta et. al. (1999) pointed out that environmental factors such parity, year of production, level of altitude and flock affected milk yield. Also, another authors, Margetin et al. (1998), Capistrak et al (2002) and Oravcova et al. (2006) analysed the environmental factors which affect daily milk yield of sheep. Test-day random regression animal model is the procedure to evaluate genetic of sheep, which used optimally way all available information (Grosu et al., 2019). This model presents the advantages: the economical costs are decreasing, it reduces the generation interval. Test-day random regression animal model was used in many studies to evaluate the sheep. In other studies, the milk breeding values for sheep were estimated whit test-day model, which is more accurate in prediction of the environmental variations associated with milk production (Othmane, 2002, Oravcova, 2006).

In the present research the purpose was the estimation of the genetic parameters using test-day milk yield in Teleorman Black Head sheep and we consider fitted to obtain the breeding value by test-day random regression animal model.

\section{MATERIALS AND METHODS}

In this study was analyzed test-day records from Teleorman Black Head Sheep breed in 3 production years $(2017,2018,2019)$ from the farm SC. OVIS CAP NEGRU from Dobrotesti, Teleorman county. The model was (Grosu 2015, 2019):

$$
y_{t i j k}=T D_{i}+\sum_{m=0}^{3}\left(\beta_{m} \cdot z_{t m}\right)+\sum_{m=0}^{3}\left(\alpha_{j m} \cdot z_{t m}\right)+\sum_{m=0}^{3}\left(\gamma_{j m} \cdot z_{t m}\right)+e_{t i j k}
$$

$y_{t i j k}=$ test day (TD) milk yield performance " $\boldsymbol{k}^{\prime}$ of ewe " $\boldsymbol{j}$ " measured at time

" $t$ ";

$\mathrm{TD}_{\mathrm{i}}=\mathrm{TD}$ effect "i"';

$\beta_{m}=$ fixed regression coefficient;

$\alpha_{j m}=$ random regression coefficients of breeding value;

$\gamma_{j m}=$ random regression coefficients for the permanent environmental

effect;

$z_{t m}=$ Legendre Polynomials at time " $t$ ";

$e t_{i j k}=$ residual error. 
In the present study to obtain the estimated breeding value was used the random regression model and Legendre polynomials of order 3 in order to obtain the additive genetic and the permanent environmental effect.

The model is:

$$
y=X_{1} b+X_{2} \beta+Z_{1} \alpha+Z_{2} \gamma+e
$$

where: $\mathrm{y}=$ vector of TD milk yield record;

$\mathrm{X}_{1}=$ incidence matrix for fixed effect

$\mathrm{b}=$ vector of fixed effect for test-day;

$\mathrm{X}_{2}=$ covariates matrix for fixed effect

$\beta=$ fixed regression coefficients

$\mathrm{Z}_{1}=$ covariates matrix for all animals

$\alpha=$ random regression coefficients for the breeding value

$\mathrm{Z}_{2}=$ covariates matrix for ewes with performances

$\gamma=$ random regression coefficients for the permanent environmental effect

$\mathrm{e}=$ vector of residual effects

The (co)variance structure was assumed for random effects of model:

$$
\mathrm{V}=\left[\begin{array}{ccc}
\mathrm{A} \otimes \mathrm{G} & 0 & 0 \\
0 & \mathrm{I} \otimes \mathrm{P} & 0 \\
0 & 0 & I \sigma_{e}^{2}
\end{array}\right]
$$

Where:

$\operatorname{Var}(\mathrm{a})=\mathrm{A} \otimes \mathrm{G}$;

$\operatorname{Var}(\mathrm{a})=$ additive variance;

Where $\otimes$ is Kronecker product function;

$\operatorname{Var}(\mathrm{p})=\mathrm{I} \otimes \mathrm{P}$;

$\operatorname{Var}(\mathrm{p})=$ environmental variance;

$\mathrm{G}$ and $\mathrm{P}$ are the matrices of genetic and permanent environmental variances and covariances between random regression coefficients.

$I$ = represents the identity matrix with the size equal with the number of ewes with records;

$\sigma_{e}^{2}=$ residual variance for lactation assumed to be constant throughout the lactation;

The estimates of heritability for milk yield during days in milk $t$ were obtained by:

where:

$$
h_{t=}^{2} \frac{g_{t t}}{\left(g_{t t}+p_{t t}+\sigma_{e}^{2}\right)}
$$

$h_{t}^{2}=$ heritability for milk yield during days in milk t;

$g_{t t}=$ genetic variance for milk yield during any days in milk $\mathrm{t}$; 


$$
\begin{aligned}
& g_{t t}=z_{t}^{I} * G * z_{t} \\
& p_{t t}=z_{t}^{I} * P * z_{t}
\end{aligned}
$$

$p_{t t}=$ permanent environmental variance for milk yield during any days in milk $\mathrm{t}$;

$z_{t}=\operatorname{co(variables)~related~to~a~specific~test~day~} \mathrm{l}$ measured during days in milk $\mathrm{t}$;

$\sigma_{e}^{2}=$ residual variance;

The estimates of genetic correlations between test-day $t^{\prime}$ and t milk yields were calculated by:

where:

$$
r_{g_{t r t}}=\frac{g_{t r t}}{\sqrt{g_{t r t r} * g_{t t}}}
$$

$r_{g_{t r t}}=$ genetic correlations between test-day $\mathrm{t}^{\prime}$ and $\mathrm{t}$ milk yields;

$g_{t r t}=$ genetic covariances between two test days during days in milk;

$z_{t \prime}^{r}=$ transpose of $\mathrm{z}$;

$$
g_{t r t}=z_{t r}^{I} * G * z_{t}
$$

\section{RESULTS AND DISCUSSION}

In the present study was observed that the daily milk yield was influenced by the stage of milk production (table 1.a).

Table 1.a Test day milk yield at Teleorman Black Head Sheep for each lactation.

\begin{tabular}{cccc}
\hline Test day & Mean & $\begin{array}{c}\text { Standard } \\
\text { deviation }\end{array}$ & Number of ewes \\
\hline Year 2017 & & & \\
\hline 1 & $0.693 \pm 0.021$ & 0.282 & 249 \\
\hline 2 & $0.648 \pm 0.022$ & 0.273 & 322 \\
\hline 3 & $0.703 \pm 0.024$ & 0.291 & 328 \\
\hline 4 & $0.894 \pm 0.028$ & 0.028 & 152 \\
\hline Year 2018 & & & \\
\hline 1 & $0.456 \pm 0.011$ & 0.23 & 374 \\
\hline 2 & $0.762 \pm 0.020$ & 0.47 & 374 \\
\hline Year 2019 & & & \\
\hline 1 & $0.798 \pm 0.02$ & 0.33 & 263 \\
\hline 2 & $0.702 \pm 0.019$ & 0.33 & 311 \\
\hline 3 & $0.433 \pm 0.012$ & 0.22 & 304 \\
\hline 4 & $0.404 \pm 0.012$ & 0.21 & 286 \\
\hline
\end{tabular}

Lambings in Teleorman Black Head Sheep are seasonal. The number of the ewes in the same lactation test-day had great impact to the milk yield 
during milk production which was associated to the flock test-day effect. The lack of milk records performances at the maximum daily milk yield are similarly with the one obtained when the milk is consummated by the lambs and these having a descending tendency to the milk production. A highly significant effect or a significant one was observed in many researches and had a great impact on the milk production and also influenced the lactation faze, Pavic et al. (2002) in Travnik sheep, by Oravcova et al $(2006,2007)$ in Tsigai, Lacaune and Improved Valachian sheep and by Kuchtick et al. (2008) in East Friesian sheep.

The results for average milk yield and standard deviation of the test day milk yield are presented in table $1 \mathrm{~b}$. The average daily milk yield in Teleorman Black Head sheep in 2017 and 2018 was higher than the daily milk yield of Tsigai breed (0.604) and Improved Valachian (0.595) and lower than the daily milk yield in Lacaune sheep (1.053) reported by Oravcova et al., (2006).

Table 1b. The average test day milk yield at Teleorman Black Head Sheep for three years lactation

\begin{tabular}{llll}
\hline Test day & Mean & $\begin{array}{l}\text { Standard } \\
\text { deviation }\end{array}$ & Number of ewes \\
\hline & & & \\
\hline 2017 & $0.711 \pm 0.012$ & 0.39 & 403 \\
\hline 2018 & $0.609 \pm 0.010$ & 0.40 & 374 \\
\hline 2019 & $0.580 \pm 0.009$ & 0.32 & 319 \\
\hline
\end{tabular}

The breeding value of the best 10 sheep from our study for lactation in 2017 ranged from 10.252 to 30.119 l, (table 2).

Table 2. The best 10 ewes in the present study, classified by the breeding value from 2017 lactation

\begin{tabular}{ll}
\hline No. & Estimated breeding value \\
\hline 1 & 30.119 \\
2 & 16.040 \\
3 & 13.992 \\
4 & 13.634 \\
5 & 13.008 \\
6 & 12.069 \\
7 & 11.863 \\
8 & 10.901 \\
9 & 10.554 \\
10 & 10.252 \\
\hline
\end{tabular}

The breeding value of the best 10 sheep from our study for lactation in 2018 ranged from 12.54 to $34.64 \mathrm{l}$, (table 3 ). 
Table 3. The best 10 ewes in the present study, classified by the breeding value from 2018 lactation

\begin{tabular}{ll}
\hline No. & Estimate breeding value \\
\hline 1 & 34.64 \\
2 & 28.55 \\
3 & 20.35 \\
4 & 19.96 \\
5 & 16.84 \\
6 & 15.97 \\
7 & 14.94 \\
8 & 13.41 \\
9 & 13.06 \\
10 & 12.54 \\
\hline
\end{tabular}

The breeding value of the best 10 sheep from our study for lactation in 2019 ranged from 5.161 to 16.566 , (table 4).

Table 4. The best 10 ewes in the present study, classified by the breeding value from 2019 lactation

\begin{tabular}{ll}
\hline No. & Estimated breeding value \\
\hline 1 & 16.566 \\
2 & 8.435 \\
3 & 6.571 \\
4 & 6.567 \\
5 & 6.161 \\
6 & 5.986 \\
7 & 5.600 \\
8 & 5.347 \\
9 & 5.197 \\
10 & 5.161 \\
\hline
\end{tabular}

The heritability for daily milk yields was shown in table 5 . For the year 2017, the low heritability was at 60 day and the high heritability was at 200 day in milk. The heritability was lower in the beginning of lactation and increasing in middle and end of lactation in production year 2018. For the year 2019 the low heritability was in 40 day of lactation and high heritability at 200 day in milk.

The heritability in the present study was in agreement with the heritability from other researches.

For milk, fat and protein yields multiple studies were undertaken with moderate results for heritability in Lacaune sheep population from France (0.24 to 0.29; Barillet and Boichard, 1987). Sarda sheep population had the same heritability value for these traits (0.24 to 0.31; Sanna et al., 1997), Churra (0.24 to 0.27; El-Saired et al., 1998, 1999). In these researches we can 
observe that heritability for milk is similar and only Latxa dairy sheep had a smaller heritability (0.16 to 0.20 ; Legarra and Ugarte, 2001).

Table 5. Heritability for daily milk yields in three different years

\begin{tabular}{llll}
\hline Days in milk & $\begin{array}{l}\text { Heritability } \\
\mathbf{2 0 1 7}\end{array}$ & $\begin{array}{l}\text { Heritability } \\
\mathbf{2 0 1 8}\end{array}$ & $\begin{array}{l}\text { Heritability } \\
\mathbf{2 0 1 9}\end{array}$ \\
\hline 10 & 0.186 & 0.243 & 0.384 \\
20 & 0.171 & 0.213 & 0.298 \\
40 & 0.152 & 0.258 & 0.186 \\
60 & 0.150 & 0.321 & 0.205 \\
80 & 0.160 & 0.344 & 0.265 \\
100 & 0.176 & 0.323 & 0.302 \\
120 & 0.193 & 0.262 & 0.306 \\
140 & 0.209 & 0.212 & 0.282 \\
160 & 0.223 & 0.307 & 0.255 \\
180 & 0.232 & 0.486 & 0.286 \\
200 & 0.237 & 0.600 & 0.403 \\
\hline
\end{tabular}

In table 6 are presented the genetic correlations obtained in the present research between test-day milk yields during the selected lactation periods.

Othmane et al., 2002 obtained the heritability and repeatability for Churra breed estimated for milk yield ( 0.26 and 0.38 ) coincided with the other results previously reported for the same breed by Carriedo et al. 1995 and El-Saied et al. 1999 [15] and other dairy ewes by Sanna et al. 1997 and Serrano et al. 2001.

Table 6. Genetic correlations between selected days in milk (DIM) of daily yields in 2017

\begin{tabular}{llllllllllll}
\hline DIM & 10 & 20 & 40 & 60 & 80 & 100 & 120 & 140 & 160 & 180 & 200 \\
\hline 10 & 1 & 0.99 & 0.92 & 0.79 & 0.64 & 0.50 & 0.38 & 0.29 & 0.21 & 0.15 & 0.10 \\
20 & 0.99 & 1 & 0.96 & 0.86 & 0.73 & 0.60 & 0.49 & 0.40 & 0.33 & 0.27 & 0.22 \\
40 & 0.92 & 0.96 & 1 & 0.96 & 0.88 & 0.79 & 0.70 & 0.62 & 0.56 & 0.50 & 0.46 \\
60 & 0.79 & 0.86 & 0.96 & 1 & 0.97 & 0.92 & 0.86 & 0.80 & 0.75 & 0.70 & 0.66 \\
80 & 0.64 & 0.73 & 0.88 & 0.97 & 1 & 0.98 & 0.95 & 0.91 & 0.87 & 0.84 & 0.80 \\
100 & 0.50 & 0.60 & 0.79 & 0.92 & 0.98 & 1 & 0.98 & 0.96 & 0.94 & 0.92 & 0.89 \\
120 & 0.38 & 0.49 & 0.70 & 0.86 & 0.95 & 0.98 & 1 & 0.99 & 0.98 & 0.96 & 0.94 \\
140 & 0.29 & 0.40 & 0.62 & 0.80 & 0.91 & 0.96 & 0.99 & 1 & 0.99 & 0.98 & 0.97 \\
160 & 0.21 & 0.33 & 0.56 & 0.75 & 0.87 & 0.94 & 0.98 & 0.99 & 1 & 0.99 & 0.98 \\
180 & 0.15 & 0.27 & 0.50 & 0.70 & 0.84 & 0.92 & 0.96 & 0.98 & 0.99 & 1 & 0.99 \\
200 & 0.10 & 0.22 & 0.46 & 0.66 & 0.80 & 0.89 & 0.94 & 0.97 & 0.98 & 0.99 & 1 \\
\hline
\end{tabular}

The genetic correlation between test-day milk yield is positive. 


\section{CONCLUSION}

The breeding value for test day milk yield for the best 10 sheep from our study for lactation in 2017 ranged from $10.252 \mathrm{~g}$ to $30.119 \mathrm{~g}$., in 2018 ranged from 12.54 to $34.64 \mathrm{l}$ and in 2019 ranged from 5.161 to 16.566 .

The heritability for test-day milk yield ranged from 0.150 to 0.237 in 2017, from 0.212 to 0.600 in 2018 and in 2019 from 0.186 to 0.403 .

Genetic correlations between sheep test-days milk yield in 2017 were positive and high.

Test day random regression model is good model for genetic evaluation of milk production for sheep, giving a better accuracy of breeding value estimates.

\section{ACKNOWLEDGEMENTS}

This study was supported by the Ministry of Agriculture and Rural Development which financed ADER project no. 8.1.10

\section{REFERENCES}

Barillet, F., and D. Boichard. Studies on dairy production of milking ewes I. Estimates of genetic parameters for total milk and composition yield, 1987, Genet. Sel. Evol. 19:459-474.

Čapistrák A., Margetín M., Apolen D., Špánik J.: Production and content of basic components in sheep milk of Improved Valachian, Lacaune breeds and their crosses, 2002, J. Farm Anim. Sci., 35, 89-96.

Carriedo J.A., Baro J.A., De La Fuente L.F., San Primitivo F., Genetic parameters for milk yield in dairy sheep, 1995, J. Anim. Breed. Genet. 112, 59-63.

El-Saied, U. M., J. A. Carriedo, J. A. Baro, L. F. de la Fuente, and F. San Primitivo. Genetic correlations and heritabilities for milk yield and lactation length of dairy sheep, 1998, Small Rumin. Res. 27:217-221.

El-Saied, U. M., J. A. Carriedo, L. F. de la Fuente, and F. San Primitivo. Genetic parameters of lactation cell counts and milk and protein yields in dairy ewes, 1999, J. Dairy Sci. 82:639-644.

Grosu, H. and Rotar M.C., Estimarea valorii de ameliorare la taurine, pe baza modelelor zilei de control (test day models), 2015, Ceres, Bucuresti.

Grosu, H., Lungu S., Oltenacu P. A., Drăgănescu C., Mateescu R. Predicția valorii de ameliorare a taurinelor, 2019, Editura Ceres.

Komprej, A., Malovrh S., Gorjanc G., Kompan D., Kovac M., Genetic and environmental parameters estimation for milk traits in Slovenia dairy sheep using random regression model, 2013, Czech J. Anim. Sci, 58, 3, 125-135 
Kuchtík J., Šustová K., Urban T., Zapletal D.: Effect of the stage of lactation on milk composition, its properties and the quality of rennet curdling in East Friesian ewes, 2008, Czech Journal of Animal Science, 53, 55-63.

Legarra, A., and E. Ugarte.: Genetic parameters of milk traits in Latxa dairy sheep, 2001, Anim. Sci. 73:407-412.

Macciotta N.P.P., Cappio-Borlino A., Pulina G. (1999). Analysis of environmental effects on test day milk yields of Sarda Dairy Ewes. J. Dairy Sci., 82:2212-2217.

Margetín M., Hlavatý Š., Přibyl J.: Effect of genetic and non-genetic factors on milk production in ewes of Improved Valachian and Tsigai breeds, 1998, J. Farm Anim. Sci., 31, 21-28.

Oravcová M., Margetín M., Peškovičová D., Daňo J., Milerski M., Hetényi L., Polák P.: Factors affecting ewe's milk fat and protein content and relationships between milk yield and milk components, 2007, Czech Journal of Animal Science, 52, 189-198.

Oravcova, M., Margetin M., Peškovičova D., Dano J., Milerski M., Hetenyi L., Polal P.: Factors affecting milk yield and ewe's lactation curves estimated with test-day models, Czech J. Anim, 2006, Sci., 51, (11): 483-490.

Othmane, M.H., De La Fuente L.F., Carriedo J.A., San Primitivo F., Heritability and genetic correlations of test day milk yield and composition, individual laboratory cheese yield, and somatic cell count for dairy ewes, 2002, Journal of Dairy Science, 85, 2692-2698

Pavic V., Antenac N., Mioc B., Ivankovic A., Havranek J. L. Influence of stage of lactation on the chemical composition and physical properties of sheep milk, 2002, Czech J.Anim. Sci., 47 (2): 80-84.

Sanna S.R., Carta A., Casu S., (Co)variance component estimates for milk composition traits in Sarda dairy sheep using a bivariate animal model, 1997, Small Ruminant Res. 25, 79-84

Serrano M., Ugarte E., Jurado J.J., Pérez-Guzmán M.D., Legarra A., Test day models and genetic parameters in Latxa and Manchega dairy ewes, 2001, Livest. Prod. Sci. 67, 253-264.

Wedholm, A., Larsen, L.B., Lindmark-Mansson, H., Karlsson, A.H., Andren, A., 2006. Effect of protein composition on the cheese-making properties of milk from individual dairy cows. J. Dairy Sci., 89, 3296-3305.

Yang, L., Yang, Q., Yi, M., Pang, Z.H., Xiong, B.H., 2013. Effects of seasonal change and parity on raw milk composition and related indices in Chinese Holstein cows in northern China. J Dairy Sci. 96, 6863-6869.

Zhang, R.F., Chen, H., Lei, C.Z., Fang X.T., Zhang Y.D., Hu S.R., Su L.H., 2007. Association between PCR- RFLP polymorphisms of five gene loci and milk traits in Chinese Holstein. Asian -Aust. J. Anim. Sci., vol. 20, no. 2: 166-171 